Check for updates

Cite this: RSC Adv., 2017, 7, 36684

\title{
The superior desorption properties of $\mathrm{MgCl}_{2}$-added ammonia borane compared to $\mathrm{MgF}_{2}$-added systems - the unexpected role of $\mathrm{MgCl}_{2}$ interacting with $\left[\mathrm{NH}_{3}\right]$ units $\dagger$
}

\author{
Xiaoli Ding, Jingjing Feng, Tianlai Xia, Xiaomin Yuan, * Dongming Liu, Yongtao Li D * \\ and Qingan Zhang (D)
}

Received 8th June 2017

Accepted 11th July 2017

DOI: $10.1039 / \mathrm{c} 7 \mathrm{ra06428d}$

rsc.li/rsc-advances

\begin{abstract}
An uncommon dehydrogenation mechanism for metal chloride-added ammonia borane $\left(\mathrm{NH}_{3} \mathrm{BH}, \mathrm{AB}\right)$ systems revealed that $\mathrm{MgCl}_{2}$ interacts with the $\left[\mathrm{NH}_{3}\right]$ units in $\mathrm{AB}$, analogous to the amine complex of $\mathrm{Mg}\left(\mathrm{NH}_{3}\right)_{x} \mathrm{Cl}_{2}$, thus not only resulting in a remarkable decrease in the hydrogen desorption temperature but also effectively suppressing undesirable volatile by-products, particularly ammonia gas.
\end{abstract}

Using hydrogen as an energy carrier is severely fettered by the key fact that there is still no safe and effective method available for storing hydrogen. ${ }^{1,2}$ To overcome this, significant effort has been focused on the possibility of using hydrides and their complexes as a solid form of hydrogen storage..$^{3-7}$ Among them, chemical hydrides, particularly ammonia borane $\left(\mathrm{NH}_{3} \mathrm{BH}_{3}, \mathrm{AB}\right)$, have been considered as promising hydrogen storage candidates due to its intrinsic high capacity of $19.6 \mathrm{wt} \%{ }^{8,9}$ More importantly, solid state $\mathrm{AB}$ can decompose below $100{ }^{\circ} \mathrm{C}$ and can be regenerated via reacting with hydrazine in liquid ammonia at a rather slow rate. ${ }^{10-12}$ Unfortunately, abundant volatile impurities such as ammonia $\left(\mathrm{NH}_{3}\right)$, diborane $\left(\mathrm{B}_{2} \mathrm{H}_{6}\right)$ or borazine $\left(\mathrm{N}_{3} \mathrm{~B}_{3} \mathrm{H}_{6}\right)$ are released along with $\mathrm{H}_{2},{ }^{13}$ which not only decreases the yield of $\mathrm{H}_{2}$ but also poisons the noble metal catalysts and Nafion membrane used in fuel cells. ${ }^{14,15}$ Thus, substantial effort has been devoted to suppressing undesirable volatile products to improve the yield of $\mathrm{H}_{2}$ and further promote its practical use as a hydrogen supply to fuel cells.

One effective approach to improve hydrogen release from $\mathrm{AB}$ is the chemical modification of its electron donor-acceptor complex structure by adding chloride salts. In an early study, Heldebrant et al. ${ }^{16}$ reported that the introduction of $\mathrm{NH}_{4} \mathrm{Cl}$ to $\mathrm{AB}$ forms an intermediate $\left[\left(\mathrm{NH}_{3}\right)_{2} \mathrm{BH}_{2}\right]^{+} \mathrm{Cl}^{-}$, which results in the rapid release of hydrogen below $90{ }^{\circ} \mathrm{C}$. Later, Chen et al. ${ }^{17}$ found that approximately $5.8 \mathrm{wt} \%$ hydrogen is evolved from $\mathrm{CoCl}_{2}-$ doped $\mathrm{AB}$ at a temperature as low as $59{ }^{\circ} \mathrm{C}$ due to the catalytic effect of partially reduced Co active species. In a subsequent report, Jagirdar et al. ${ }^{18}$ proposed that by milling $\mathrm{AB}$ with $\mathrm{CuCl}_{2}$ we

School of Materials Science and Engineering, Anhui University of Technology, Maanshan, 243002, China. E-mail: yuan@ahut.edu.cn; toni-li@163.com; Fax: +86555-2311570; Tel: +86-555-2311570

$\dagger$ Electronic supplementary information (ESI) available: Materials preparing and measurements, Fig. S1-S3. See DOI: 10.1039/c7ra06428d can achieve facile desorption at about $60{ }^{\circ} \mathrm{C}$ through an intermediate $\left[\mathrm{NH}_{4}\right]^{+}\left[\mathrm{BCl}_{4}\right]^{-}$phase without borazine emission. Following these observations, our recent study showed that the incorporation of alkaline earth metal chlorides into $\mathrm{AB}$ can further decrease the desorption temperature to be as low as $50^{\circ} \mathrm{C}$ and suppress the formation of undesirable volatile by-products. ${ }^{19}$ However, a rival determination of how the modification of alkaliearth metal chlorides into $\mathrm{AB}$ decomposition occurs is lacking and the underlying mechanism is not well understood. More recently, Nakagawa et al. ${ }^{20}$ further found that the $\mathrm{M}^{n+}$ of $\mathrm{MCl}_{n}$ with high electronegativity $\left(\chi_{\mathrm{p}}\right)$ acts as a Lewis acid and initiates the $\mathrm{AB}$ dehydrocoupling reaction by inducing changes in the electronic state of $\mathrm{N}$. Different from all of the above studies, using a comparative mechanism study among pristine, $\mathrm{MgCl}_{2}$ - and $\mathrm{MgF}_{2}$-added $\mathrm{AB}$ systems, we obtained results presented here that reveal a new dehydrogenation mechanism. In the mechanism, the $\mathrm{MgCl}_{2}$ unexpectedly interacts with the $\left[\mathrm{NH}_{3}\right]$ units in $\mathrm{AB}$, analogous to the amine complex of $\mathrm{Mg}\left(\mathrm{NH}_{3}\right)_{x} \mathrm{Cl}_{2}$, which results in lowering the thermodynamic threshold as well as concomitantly inhibiting undesirable volatile by-products.

The synchronous MS and TG profiles in Fig. 1 show the hydrogen desorption properties of the pristine $\mathrm{AB}$ and ballmilled $\mathrm{MgX}_{2}(\mathrm{X}=\mathrm{F}, \mathrm{Cl}) / \mathrm{AB}$ (molar ratio, $1: 2$ ) samples. For the detected MS spectrum of $\mathrm{H}_{2}$ (Fig. 1a), two consecutive peaks at $\sim 110$ and $\sim 154{ }^{\circ} \mathrm{C}$ were observed for the pristine $\mathrm{AB}$, being consistent with the reported values. ${ }^{21}$ Similar peaks somewhat downshifted were also determined in the $\mathrm{MgF}_{2} / 2 \mathrm{AB}$ sample. Compared to them, an evident shift to a lower temperature was obtained in $\mathrm{H}_{2}$-MS spectrum for the $\mathrm{MgCl}_{2} / 2 \mathrm{AB}$ sample, whereby the release of hydrogen started at approximately $40^{\circ} \mathrm{C}$, with the first peak appearing at approximately $60{ }^{\circ} \mathrm{C}$ (similar to the decomposition of a $\mathrm{SrH}_{2}+\mathrm{AB}$ mixture ${ }^{22}$ ) and was completed below $130{ }^{\circ} \mathrm{C}$ (see Fig. S1 (ESI $\dagger$ ) for partial enlarged details). More excitingly, considerable amounts of volatile by-products 

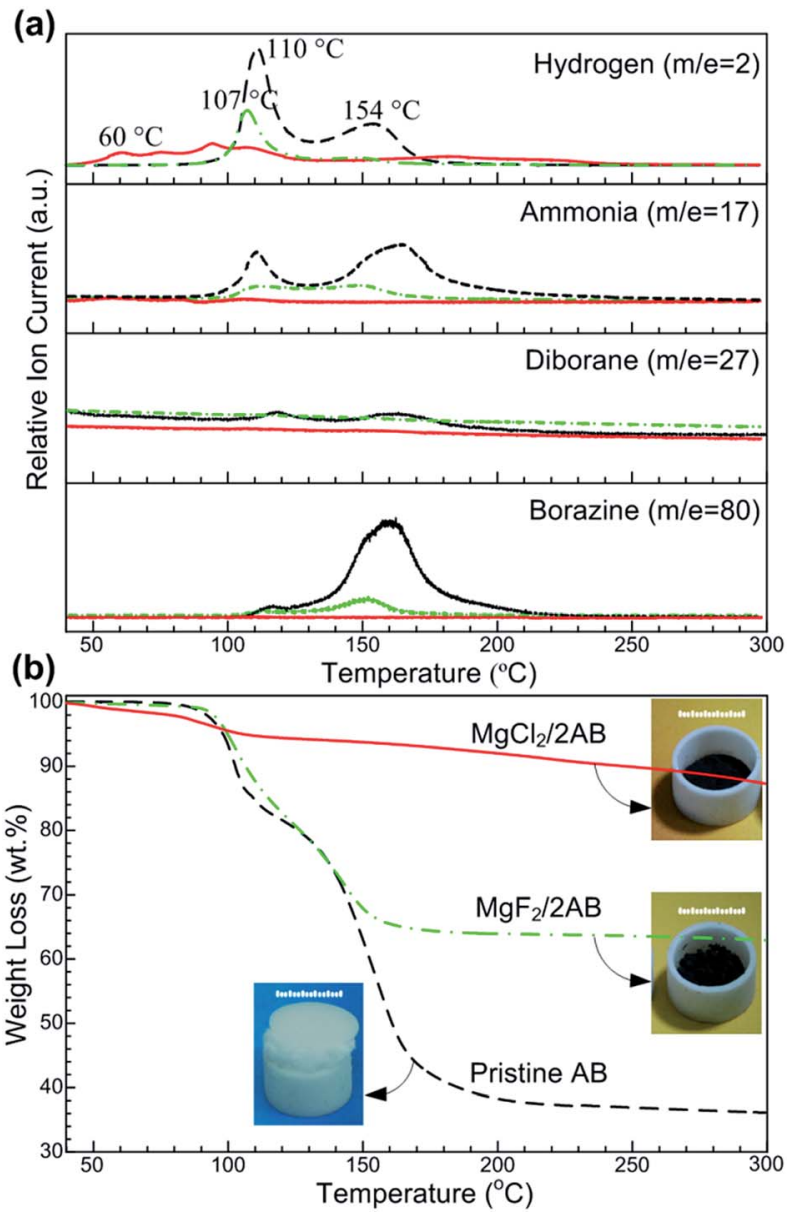

Fig. 1 (a) The MS profiles of $\mathrm{m} / \mathrm{z}=2$ (hydrogen, $\mathrm{H}_{2}$ ), 17 (ammonia, $\mathrm{NH}_{3}$ ), 27 (diborane, $\mathrm{B}_{2} \mathrm{H}_{6}$ ) and 80 (borazine, $\mathrm{C}-(\mathrm{NHBH})_{3}$ ) for pristine $\mathrm{AB}$ (black dashed line), $\mathrm{MgF}_{2} / 2 \mathrm{AB}$ (green dot-dashed line) and $\mathrm{MgCl}_{2} / 2 \mathrm{AB}$ (red solid line), and (b) their synchronous TG curves; the ramping rate was $5{ }^{\circ} \mathrm{C} \mathrm{min}{ }^{-1}$. The inserts are the optical photographs of these samples after heating in an argon flow. The sample loading was approximately $2.5 \mathrm{mg}$. The scale bar is $5 \mathrm{~mm}$.

including $\mathrm{NH}_{3}, \mathrm{~B}_{2} \mathrm{H}_{6}$ and $\mathrm{N}_{3} \mathrm{~B}_{3} \mathrm{H}_{6}$ were obtained for both the pristine $\mathrm{AB}$ and $\mathrm{MgF}_{2} / 2 \mathrm{AB}$ samples, while not detectable or negligible volatile by-products were observed for the $\mathrm{MgCl}_{2} / 2 \mathrm{AB}$ sample. These remarkable suppressions of volatile by-products were further demonstrated by the reduced weight loss detected by TG analysis. As shown in Fig. 1b, the weight loss of $\sim 64 \mathrm{wt} \%$ for pristine $\mathrm{AB}$ was in two steps and was observed at around 108 and $155^{\circ} \mathrm{C}$, along with the severe expansion that pushed up the lid of the crucible (see photograph in Fig. 1b). This should be attributed to the decomposition of $\mathrm{AB}$ into polymeric aminoboranes $\left(\left(\mathrm{NH}_{2} \mathrm{BH}_{2}\right)_{n}, \mathrm{PAB}\right)$ and polymeric iminoboranes $\left((\mathrm{NHBH})_{n}, \mathrm{PIB}\right)$ solid residues. ${ }^{15,23}$ Similarly, the $\mathrm{MgF}_{2} / 2 \mathrm{AB}$ sample also exhibited a two-step decomposition with an inflated feature. Its weight loss of $\sim 34 \mathrm{wt} \%$ was comparable with the weight loss from $\mathrm{AB}$ in the mixture ( $32 \mathrm{wt} \%)$. These obtained weight loss results were far larger than the expected $\mathrm{H}$-content of $13 \mathrm{wt} \%$ in $\mathrm{AB}$, further demonstrating the emission of undesirable volatile by-products, as shown in Fig. 1a. In contrast, the $\mathrm{MgCl}_{2} / 2 \mathrm{AB}$ did not exhibit any detectable foaming (see
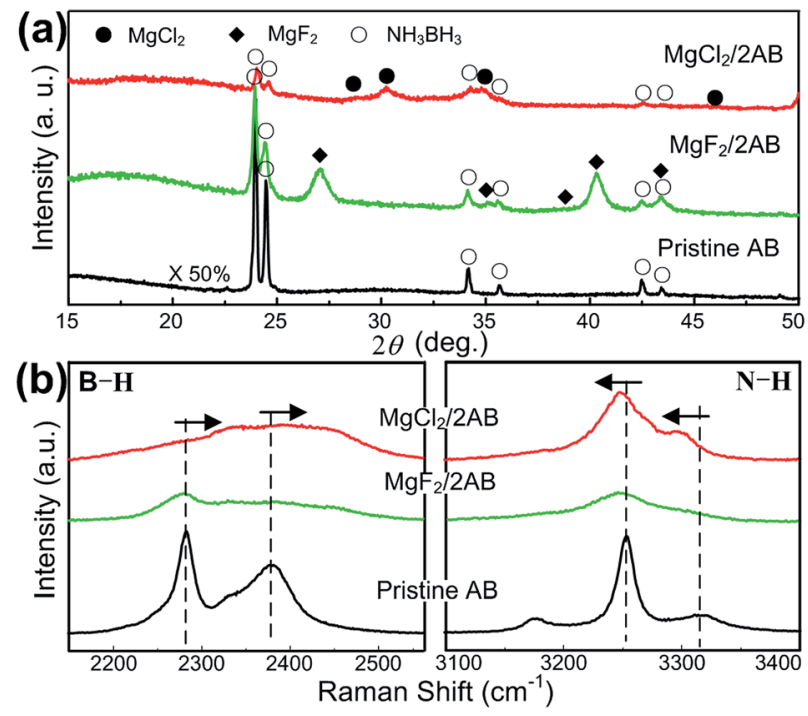

Fig. 2 (a) The XRD patterns and (b) Raman spectra recorded for the post-milled $\mathrm{AB}, \mathrm{MgCl}_{2} / 2 \mathrm{AB}$ and $\mathrm{MgF}_{2} / 2 \mathrm{AB}$ samples without heating.

photograph in Fig. 1b), only with a weight loss of $12 \mathrm{wt} \%$, which was close to the theoretical hydrogen capacity of $\mathrm{AB}(\sim 13 \mathrm{wt} \%)$. These tremendous contrasts presented by both the TG analysis and optical photographs strongly suggest the suppression of volatile by-products via their distinct decomposition routes.

To reveal the intrinsic reason for the superior desorption properties of $\mathrm{MgCl}_{2} / 2 \mathrm{AB}$ compared to $\mathrm{MgF}_{2} / 2 \mathrm{AB}$ and pristine $\mathrm{AB}$, the structural features of the samples during the milling and heating processes were examined carefully. First, the milled samples were examined by XRD and Raman scattering spectroscopy. It was found that all the peaks can be indexed by the starting phases of $\mathrm{AB}, \mathrm{MgCl}_{2}$ and $\mathrm{MgF}_{2}$ (see Fig. 2a) without new peaks being detected, indicating that the solid-state reaction between $\mathrm{AB}$ and $\mathrm{MgX}_{2}$ did not occur upon the initial milling step. However, the chemical bonding states of these samples exhibited different results. As shown in Fig. 2b, all the vibrational modes of the typical B-H stretches at $\sim 2281$ and $2380 \mathrm{~cm}^{-1}$, and the $\mathrm{N}-\mathrm{H}$ stretches at $\sim 3251$ and $3318 \mathrm{~cm}^{-1}$ for the $\mathrm{MgX}_{2} / 2 \mathrm{AB}$ samples became significantly broader and weaker relative to those modes for the pristine and post-milled AB (see Fig. S2 (ESI †)), suggesting the reduced bonding stability. ${ }^{24}$ More interestingly, an evident upfield shift for the B-H stretches and a downfield shift for the $\mathrm{N}-\mathrm{H}$ stretches were observed for $\mathrm{MgCl}_{2} / 2 \mathrm{AB}$ compared with the shifts observed for the pristine $\mathrm{AB}$ and $\mathrm{MgF}_{2} / 2 \mathrm{AB}$ samples, which strongly indicates that the chemical modification was started during the solid phase ball-milling step upon adding $\mathrm{MgCl}_{2}$. The changed bonding structure caused by $\mathrm{MgCl}_{2}$ but not $\mathrm{MgF}_{2}$ may alter the reaction pathway of $\mathrm{AB}$, thus leading to favourable thermal decomposition behaviour, as shown in Fig. 1.

Second, the $\mathrm{MgX}_{2} / 2 \mathrm{AB}$ samples after heating at $130{ }^{\circ} \mathrm{C}$ were further analysed by XRD and solid-state NMR techniques to determine the difference in their phase and bonding states. As shown in Fig. 3a, only $\mathrm{MgF}_{2}$ peaks were observed in the $\mathrm{MgF}_{2}-$ doped samples after heating, indicating the single $\mathrm{AB}$ decomposition and its resulting products with an amorphous nature. 

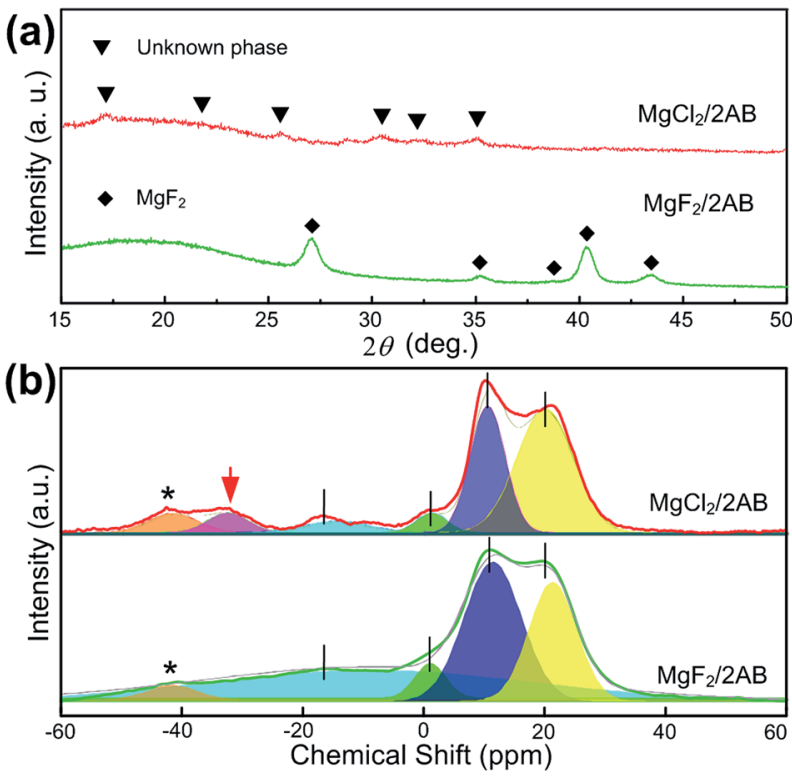

Fig. 3 (a) The XRD patterns and (b) ${ }^{11} \mathrm{~B}$ NMR spectra for the $\mathrm{MgF}_{2} / 2 \mathrm{AB}$ and $\mathrm{MgCl}_{2} / 2 \mathrm{AB}$ samples after heating at $130^{\circ} \mathrm{C}$. The spinning sidebands are marked with asterisks (*).

Different from it, only some unknown phases that did not match both the initial $\mathrm{AB}$ and $\mathrm{MgCl}_{2}$ were obtained in the $\mathrm{MgCl}_{2}$-doped sample after heating, strongly suggesting the $\mathrm{MgCl}_{2}$ was involved in the desorption of $\mathrm{AB}$ but not for the $\mathrm{MgF}_{2}$-doped sample. Furthermore, except for the similar tridentate ${ }^{11} \mathrm{~B}$ NMR spectra that are possibly related to the single or two overlapping quadrupolar resonances of $\mathrm{BN}_{3}, \mathrm{BN}_{2} \mathrm{H}$ or even a mixture of both, an additional peak at approximately $-35 \mathrm{ppm}$ was obtained for the $\mathrm{MgCl}_{2}$-doped sample after heating, which can be most likely assigned to the unknown phase, as shown in Fig. 3a, i.e., the complex of $\mathrm{MgCl}_{2}$ with $\mathrm{AB}$ after heating at $130{ }^{\circ} \mathrm{C} .^{25,26}$

Third, we further employed in situ Raman spectroscopy to examine the entire process of thermal decomposition. Fig. 4 exhibits the in situ Raman spectra for pristine $\mathrm{AB}$ and $\mathrm{MgX}_{2} / 2 \mathrm{AB}$ during the heating process from room temperature to $250{ }^{\circ} \mathrm{C}$. For the pristine $\mathrm{AB}$ sample, the symmetric stretching bands of the $\mathrm{B}-$ $\mathrm{N}, \mathrm{B}-\mathrm{H}$ and $\mathrm{N}-\mathrm{H}$ bonds were gradually weakened at temperatures over $100{ }^{\circ} \mathrm{C}$ and completely disappeared at about $125{ }^{\circ} \mathrm{C}$, which corresponded to the first emission of volatile by-products (Fig. 1a). The second emission of volatile by-products between $125^{\circ} \mathrm{C}$ and $200{ }^{\circ} \mathrm{C}$ became illegible because of their initial remarkable relative intensity. Moreover, $\mathrm{MgF}_{2} / 2 \mathrm{AB}$ exhibited a similar curve except for two perpetual peaks at approximately 1250 and $3100 \mathrm{~cm}^{-1}$, which were most probably due to the fluorescent effect of $\mathrm{MgF}_{2}$. This explains why they showed similar thermal decomposition behavior (Fig. 1). In contrast, the $\mathrm{B}-\mathrm{N}, \mathrm{N}-\mathrm{H}$ and $\mathrm{B}-\mathrm{H}$ stretching bands weakened at around $40{ }^{\circ} \mathrm{C}$ for the $\mathrm{MgCl}_{2} / 2 \mathrm{AB}$ sample and were in good agreement with the TG/MS results shown in Fig. 1. The intensity of these bands rapidly decreased and the bands further disappeared as the temperature increased to $130{ }^{\circ} \mathrm{C}$. More remarkably, with the disappearance of the $\mathrm{B}-\mathrm{N}, \mathrm{N}-\mathrm{H}$ and $\mathrm{B}-\mathrm{H}$ bands, two fresh bands emerged at $505 \mathrm{~cm}^{-1}$ and $916 \mathrm{~cm}^{-1}$, which could not be identified as any known B-, N- and $\mathrm{Mg}$ -
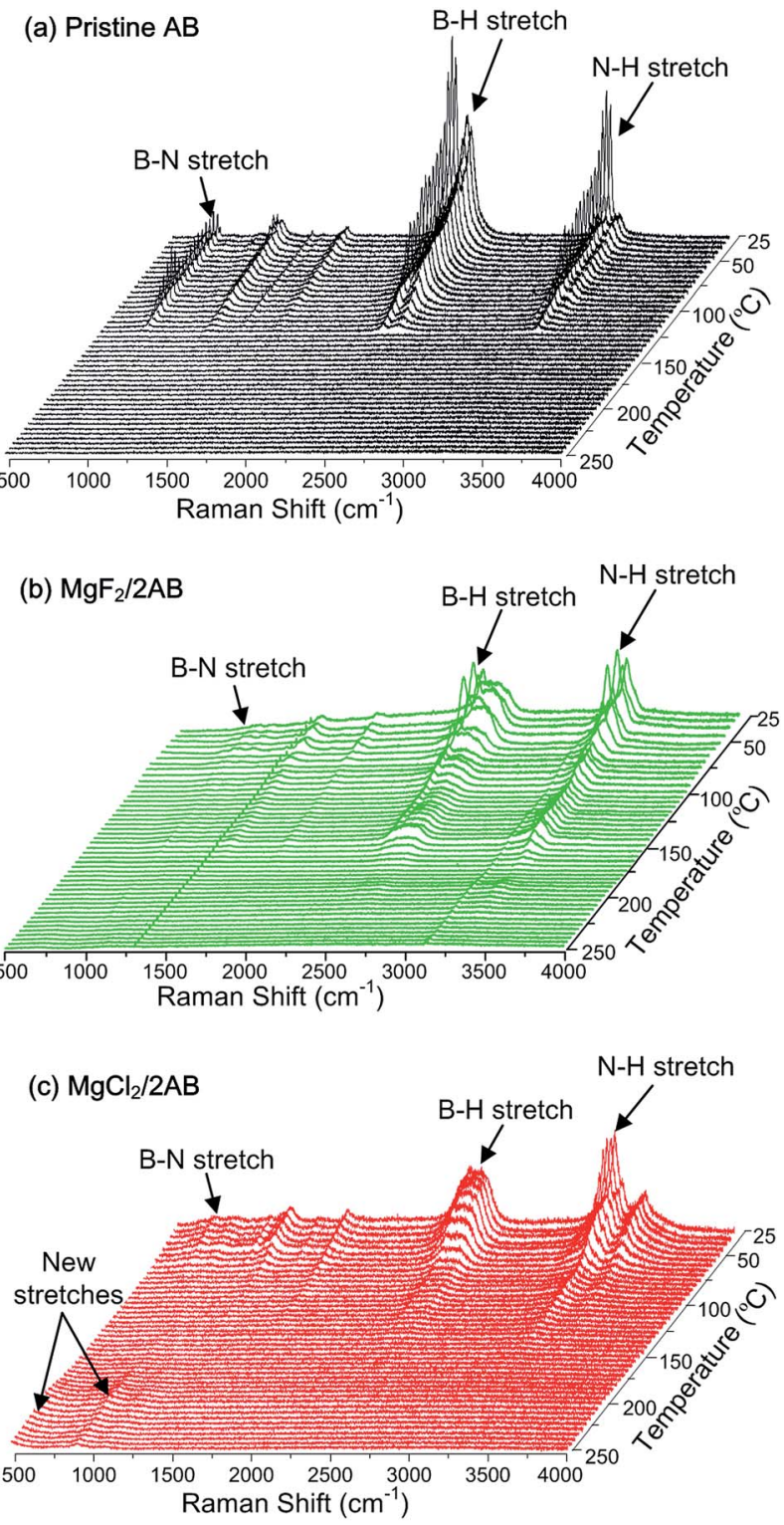

Fig. 4 The temperature-dependent Raman spectra recorded for the thermal decomposition of (a) pristine $\mathrm{AB}$, (b) $\mathrm{MgF}_{2} / 2 \mathrm{AB}$ and (c) $\mathrm{MgCl}_{2} /$ $2 A B$ upon heating from room temperature to $250{ }^{\circ} \mathrm{C}$.

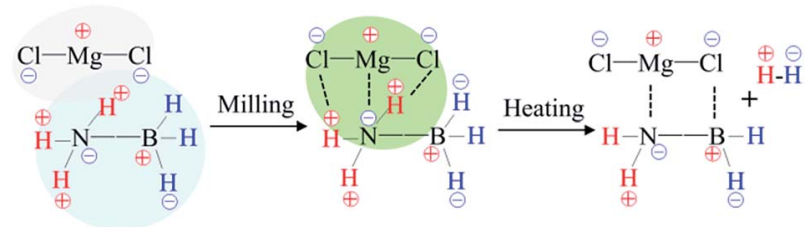

Scheme 1 The proposed route for the dehydrogenation of $A B$ activated by $\mathrm{MgCl}_{2}$.

containing compounds. ${ }^{27-29}$ With increasing temperature, the intensity of these fresh bands was observed to increase slightly. Combining the TG/MS (Fig. 1) and XRD/NMR (Fig. 2 and 3) results, the resulting product could be preliminarily deduced to be 
a $\mathrm{Mg}-\mathrm{N}-\mathrm{B}-\mathrm{Cl}-\mathrm{H}$ complex. In this regard, a complete overview by employing componential determination/theoretical calculations is currently underway in our laboratory. More interestingly, upon further heating to $600{ }^{\circ} \mathrm{C}$ (see Fig. S3 ( $\mathrm{ESI}_{\dagger} \dagger$ )), the $\mathrm{MgCl}_{2}$ peaks were recovered in the $\mathrm{XRD}$ pattern. This strongly suggests that an uncommon mechanism for the $\mathrm{MgCl}_{2}$ was involved in the $\mathrm{AB}$ decomposition. This mechanism was different from the existing desorption mechanism of the other metal chloride doped $A B$, such as catalytic effect of the in situ formed nano-metals in $\mathrm{CuCl}_{2}$, $\mathrm{CoCl}_{2}$ and $\mathrm{NiCl}_{2}$ doped $\mathrm{AB}$ systems, ${ }^{17,18}$ as well as $\mathrm{B}-\mathrm{H}$ bonds activated by partially substituting the $\mathrm{H}$ of the $\left[\mathrm{BH}_{3}\right]$ group with $\mathrm{Cl}$ anions for the $\mathrm{NH}_{4} \mathrm{Cl}$ added $\mathrm{AB}$ system. ${ }^{\mathbf{1 6}}$

In terms of the abovementioned properties and structural analyses, it is reasonable to deduce that in the $\mathrm{MgCl}_{2} / \mathrm{AB}$ system, $\mathrm{MgCl}_{2}$ first interacted with the $\left[\mathrm{NH}_{3}\right]$ units of the $\mathrm{AB}$ molecule due to the strong electron donor-acceptor coupling observed under the milling effect, as shown in Scheme 1. This interaction is similar to the ligand effect of $\mathrm{MgCl}_{2}$ with $\mathrm{NH}_{3}$ in the amine complex of $\mathrm{Mg}\left(\mathrm{NH}_{3}\right)_{x} \mathrm{Cl}_{2},{ }^{30}$ which not only results in suppressing $\mathrm{NH}_{3}$ release (Fig. 1a), but also changes the bonding state of $\mathrm{N}-\mathrm{H}$ and $\mathrm{B}-\mathrm{H}$ (Fig. 2b). Along with heating, the routine combination of $\mathrm{H}^{+} / \mathrm{H}^{-}$ will release $\mathrm{H}_{2}$ gas. Moreover, the electronegative $\mathrm{Cl}^{-}$is able to coordinate with the electropositive $\mathrm{B}$ atom via its lone electronic pairs, thus resulting in the occurrence of those unknown intermediates as confirmed by the XRD and Raman patterns (Fig. 3 and 4). When heated to $600{ }^{\circ} \mathrm{C}$ (Fig. S3 (ESI $\dagger$ )), these intermediates further decompose into conventional amorphous B-N polymerides and unexpected $\mathrm{MgCl}_{2}$ crystals. This magical disappearance/ reappearance of $\mathrm{MgCl}_{2}$ strongly confirms that an unusual desorption mechanism exists in the $\mathrm{MgCl}_{2}$-doped $\mathrm{AB}$ system, i.e., the initial ligand interaction of $\mathrm{MgCl}_{2}$ and $\mathrm{NH}_{3} \mathrm{BH}_{3}$ only disturbs the $\mathrm{B}-\mathrm{N}, \mathrm{B}-\mathrm{H}$ and $\mathrm{N}-\mathrm{H}$ bonding, but does not combine with them to form any stable compounds, thus leading to its superior properties compared to the pristine and $\mathrm{MgF}_{2}$-doped $\mathrm{AB}$ samples.

In summary, it has been demonstrated that the hydrogen from $\mathrm{AB}$ is released at a temperature as low as $40{ }^{\circ} \mathrm{C}$, and the release of undesirable volatile gases (especially for $\mathrm{NH}_{3}$ ) is remarkably suppressed upon the addition of the $\mathrm{MgCl}_{2}$. These improvements are attributed to the $\mathrm{MgCl}_{2}$ unexpectedly interacting with the $\left[\mathrm{NH}_{3}\right]$ units in $\mathrm{AB}$, analogous to the amine complex of $\mathrm{Mg}\left(\mathrm{NH}_{3}\right)_{x} \mathrm{Cl}_{2}$. These results not only deepen the understanding of the desorption mechanism of metal chloride$\mathrm{AB}$ systems, but also provides further insight into the promotion of hydrogen release from metal amidoborane and related borohydride amine complexes.

\section{Acknowledgements}

This study was financially supported by the National Natural Science Foundation of China (No. 51671001, U1503192) and the Natural Science Foundation of Anhui Province (No. 1708085ME99).

\section{Notes and references}

1 L. Schlapbach and A. Zuttel, Nature, 2001, 414, 353.

2 Y. Kojima and Y. Kawai, Chem. Commun., 2004, 19, 2210.
3 Y. Li, F. Fang, Q. Zhang, L. Ouyang, M. Zhu and D. Sun, Acta Mater., 2011, 59, 1829.

4 Q. Zhang, Y. Nakamur, K. Oikaw, T. Kamiyam and E. Akiba, Inorg. Chem., 2002, 41, 6547.

5 Q. Zhang, M. Fang, T. Si, F. Fang, D. Sun, L. Ouyang and M. Zhu, J. Phys. Chem. C, 2010, 114, 11686.

6 G. Xia, D. Li, X. Chen, Z. Tang, Z. Guo and X. Yu, Adv. Mater., 2013, 25, 6238.

7 Y. Li, X. Ding and Q. Zhang, Sci. Rep., 2016, 6, 31144.

8 A. Rossin and M. Peruzzini, Chem. Rev., 2016, 116, 8848.

9 D. W. Himmelberger, C. W. Yoon, M. E. Bluhm, P. J. Carroll and L. G. Sneddo, J. Am. Chem. Soc., 2009, 131, 14101.

10 H. Diyabalanage, R. Shrestha, T. Semelsberger, B. Scott, M. Bowden and B. Davis, Angew. Chem., Int. Ed., 2007, 46, 8995.

11 Q. Zhang, C. Tang, C. Fang, F. Fang, D. Sun, L. Ouyang and M. Zhu, J. Phys. Chem. C, 2010, 114, 1709.

12 Z. Xiong, G. Wu, Y. Chua, H. Hu, T. He, W. Xu and P. Chen, Energy Environ. Sci., 2008, 1, 360.

13 N. C. Smythe and J. C. Gordon, Eur. J. Inorg. Chem., 2010, 4, 509.

14 N. J. Hess, M. E. Bowden, V. M. Parvanov, C. Mundy, S. M. Kathman and G. Schenter, J. Chem. Phys., 2008, 128, 034508.

15 V. S. Nguyen, M. H. Matus, D. J. Grant, M. T. Nguyen and D. A. Dixon, J. Phys. Chem. A, 2007, 111, 8844.

16 D. J. Heldebrant, A. Karkamkar, N. J. Hess, M. Bowden, S. Rassat and F. Zheng, Chem. Mater., 2008, 20, 5332.

17 T. He, Z. Xiong, G. Wu, H. Chu, C. Wu, T. Zhang and P. Chen, Chem. Mater., 2009, 21, 2315.

18 S. Kalidindi, J. Joseph and B. Jagirdar, Energy Environ. Sci., 2009, 2, 1274.

19 Y. Li, F. Fang, Y. Song, Y. Li, Q. Zhang, L. Ouyang, M. Zhu and D. Sun, Int. J. Hydrogen Energy, 2012, 37, 427.

20 Y. Nakagawa, T. Zhang, M. Kitamura, S. Isobe, S. Hino, N. Hashimoto and S. Ohnuki, J. Chem. Eng. Data, 2016, 61, 1924.

21 J. Huang, Y. Tan, Q. Gu, L. Ouyang, X. Yu and M. Zhu, J. Mater. Chem. A, 2015, 3, 5299.

22 Q. Zhang, C. Tang, C. Fang, F. Fang, D. Sun, L. Ouyang and M. Zhu, J. Phys. Chem. C, 2010, 114, 1709.

23 C. R. Miranda and G. Ceder, J. Chem. Phys., 2007, 126, 184703.

24 X. Ding, Y. Li, F. Fang, D. Sun and Q. Zhang, J. Mater. Chem. $A, 2017,5,5067$.

25 L. Gao, Y. H. Guo, Q. Li and X. B. Yu, J. Phys. Chem. C, 2010, 114, 9534.

26 M. Mostajeran, D. J. Wolstenholme, C. Frazee, G. S. McGrady and R. T. Baker, Chem. Commun., 2016, 52, 2581.

27 A. M. Heyns and L. C. Prinsloo, J. Solid State Chem., 1998, 137, 33.

28 L. Machtoub, Y. Takano and H. Kito, Phys. C, 2006, 445-448, 478.

29 R. G. Schlecht and H. K. Bockelmann, Phys. Rev. Lett., 1973, 31, 930.

30 C. H. Christensen, R. Z. Sørensen, T. Johannessen, U. J. Quaade, K. Honkala, T. D. Elmøe, R. Køhler and J. K. Nørskov, J. Mater. Chem., 2005, 15, 4106. 